\title{
Father’s Character Analysis in Dangal
}

\author{
XU Jian-gang, ZHENG Xiao-yu \\ China Three Gorgeous University, Yichang, China
}

\begin{abstract}
A work's theme, significance, thought and influence are embodied by the characters' personality and behavior. Thus, the protagonists appear to be particularly important. They represent the main ideas of the work and the author's intention. Dangal (English: Wrestling competition) is a 2016 Indian Hindi-language biographical sports drama film directed by Nitesh Tiwari. Produced by Walt Disney Pictures, Aamir Khan Productions and UTV Motion Pictures, it stars Aamir Khan as Mahavir Singh Phogat, an amateur wrestler, who trains his daughters Geeta Phogat and Babita Kumari to be world-class wrestlers, both of who go on to win medals at the 2010 Commonwealth Games. The paper will enhance people's comprehension to the Indian film—Dangal and the paternal love under the patriarchal domination through the analysis of the father Mahavir Singh Phogat.
\end{abstract}

Keywords: Dangal, paternity, paternal love

\section{Introduction}

Aamir Khan, played the father Mahavir Singh Phogat in Dangal, is the hallmark of Indian film. His several representative works all point out problems and speak for the people. For example, Three Idiots' satire to the educational system, $P$. K’s query and criticism to Indian religion and Rang De Basanti's denounce to Indian political system. His new work—Dangal still reflects the social problems of India. The main idea of Dangal: Mahavir Singh Phogat (Aamir Khan) is a former amateur wrestler and national champion based in Balali, a village in Haryana. He was forced by his father to give up the sport in order to obtain gainful employment. Dejected that he could not win a medal for his country, he vows that his unborn son will. Disappointed upon having four daughters, he gives up hope. But when his older daughters Geeta and Babita come home after beating up two boys in response to derogatory comments, he realizes their potential to become wrestlers and begins coaching them. Both daughters go on to win medals at the 2010 Commonwealth Games. Babita won a silver medal at the Games, in the 51kg class and gold at the 2014 Glasgow Games in the 55kg class. In 2012, Geeta became the first Indian female wrestler to qualify for the Olympics. Mahavir's efforts inspired dozens of Indian women to take to wrestling. The story is interesting but also causes a series of social events about public opinion and religion. Despite the difficulties, Geeta finally won the championship in Commonwealth Games. From the release of the film is the banner of feminism and emphasize the difficult process of female awakening. However, the awakening of the heroine in the film cannot be separated with her father. Under the patriarchal society in India, a father regardless of public opinion by means of wrestling to let his daughters to obtain the rights of freedom and 
choice. All the strictly training and cruel means show his deep paternal love.

\section{The Dream Catcher}

Human beings are great because they have dreams. Dream is a kind of the things that make one feel the persistence is happiness. And furthermore, dream can even be regarded as a belief. In Dangal, Mahavir Singh Phogat (Aamir Khan) is a former amateur wrestler and national champion based in Balali, a village in Haryana. His dream is to win a gold medal in a world-class wrestling match for his beloved country-India. He never stopped training wrestler. Driven by Mahavir's constant efforts and dreams, he finally became a promising national wrestler. However, Mahavir from poor family demands help, fund fromthe Ministry of Sports that had never come. Mahavir was forced to give up his career because of living and his biggest regret is not able to win a National gold medal for his country. After retirement, Mahavir still shows great enthusiasm to wrestling. At work, he plays wrestling with an arrogant state-level wrestler in the office, and he gets the respect of everyone in sight after he won the match. After work, Mahavir often goes to the wrestling field in the town to watch those young wrestlers' training and rewards the winner money. After the marriage, Mahavir puts his unfinished hope in his unborn son. Thus, he looks about for the tricks to making his wife bear a son, but God plays a trick on him. His wife has four daughters at last. In the dispirited and the discouraged, Mahavir has collect the former certificate and gold medal, and ready to spend the rest of his life in mediocrity. What does not come to mind is that his eldest daughter Geeta and the second daughter Babita have shown outstanding talent on wrestling when they fighting with two boys. He finally awakens to the truth that even girls can hold their heads high and stand on the playing field to win the honor for the country and themselves.

Although Mahavir has the desire to realize the dream on his daughters, and forces them to practice wrestling, it is all built on discovering his daughter's wrestling talent. In this way, under the guidance of Mahavir, Geeta and Babita begin their tough and rigid discipline. They make rapid progress and become the local celebrities soon after winning wrestling matches one after another. Wrestling not only makes Geeta and Babita free from prejudices and endless housework and let them break out of the fate of getting married at 14-year-old, but also let them step into the wider world.

\section{The Ruler of Family}

Feminists have discovered from the history of human civilization that women are a subject of oppression and discrimination all over the world, and that they are the images of "the other". This is a universal and enduring phenomenon. Women's oppression encompasses both social and family areas. In sexual politics, Kate Millett introduced the concept of "patriarchal system" or "patriarchy" for the first time in feminist theory, and she expanded its meaning: one refers to men dominate women, the other refers to paternal figures rule the younger generation (Kate, 2000). In the film, the father Mahavir's patriarchal domination mainly shows in the following two aspects.

\section{The Patriarchal Domination in Mahavir's Family.}

In order to insist on his own dream that win a gold medal in a world-class wrestling match for his beloved country, Retired Mahavir puts this unfinished hope in his unborn son. however, he does not get any son though he took a lot of absurd behavior for getting a son. His wife gave birth to four daughters one by one. During this 
course, Mahavir's wife did not have the right to speak, only played a role of baby factory. It is enough to reflect Mahavir's patriarchal family view that son preference. The truth that four daughters prattle about his knees makes him face the reality. He quietly put the gold medal of bygone glories that he won on the national wrestling match into the box with dejected and disappointed. Fortunately, all his daughters are well-behaved to help their mother to share the busy housework. The obedient clever daughters make Mahavir feel relieved. Because of coincidence he discovered the daughter's potential of wrestling by fighting with two boys. Geeta and Babita became their father's second best helpless choice without meaning to. In the society which Mahavir lives, a woman should get married when she is 14 years old. Then she is supposed to devoted herself into family from the day she married and serve both the husband and the child. Thus, female wrestling is not promising. Women who play wrestling will not be married into the decent and rich family. But Mahavir demands his wife support his choice and forces his daughter to fulfill his dream with a tough stance.

As a father, Mahavir is not only the most selfish person but also the most "immoral” parent at this time. In order to achieve his personal ideal, he sacrifice daughters' teenage years, let them bear the shortsighted and public opinion, and let them lose the innocent time young girls should enjoy. In order to realize his dream, he even betrayed faith and tradition. His success is only a rare case of very few people. If the training of the Geeta and Babita have failed, it would be unthinkable where they decide to go in their future life. As a father, he has never thought about this. For the two daughters, he maintains the tie between family only by his desperate winning mindset at this time.

\section{Mahavir's Power Education to the Daughters.}

Mahavir is very strict to train his daughters to become a wrestler. His methods seem harsh, including grueling early morning workouts and short haircuts to avoid lice. Despite facing backlash from the villagers, he goes ahead with them, training them in his makeshift mud pit. He did all the things that villagers should not let girls do. From then on, in school and village, Geeta and Babita have been insulted and ridiculed by everyone. However, like father like son, and under the father's power, initially Geeta and Babita are rebellious by slowing down their dad's alarm, making the lights broken, pretending to get hurt, and so on. The worst part is that they drop training all day to attend a friend's wedding. The wedding scenes use the comparative expression technique: all the guests are singing and dancing lively. As the protagonist of this wedding, only the bride looks coldly at everything in an extraordinary festive atmosphere. On her face, there is not any smile matches with the wedding banquet. When the wedding is interrupted by the indignant Mahavir, Geeta and Babita complaine to the bride about their father. The bride, however, has expressed admiration that they have such a father who is considering for daughters' future. She envies them because they can wrestle and to choose their own life rather than the destiny is written from birth as her. She did chores from childhood, married to a strange man at 14-year-old and served the husband and the child lifetime. After listening few wise words from their friend, Geeta and Babita have really understand the meaning of wrestling for them.

Although wrestling is Mahavir's own dream, it has great significance to train daughters to be a wrestler. He knows that even in a patriarchal society like India, once his daughters are successful, they somehow can master their own fate. Thus, when his wife doubted her daughters cannot marry decent and rich man as a wrestler, Mahavir said that those men were not qualified to choose their daughters, instead, his daughters had the right to 
choose them. All in all, whether power education is good or not should make decision on a "case by case" basis. Firstly, it depends on whether parents have the ability to identify and foresee their children's talents. Secondly, how much wisdom and ability the parents themselves have to implement the right educational program. In the film, Mahavir has such an insight and his daughters also have the gift of wrestling. Sometimes, some teenagers need a kind of power to promote, especially for those whose views of right and wrong are imperfect, and those who do not have their own judgements and discriminability. For Mahavir knows that only his daughters strong enough, will they gain freedom. Some critics think it violates the "feminist" that father forces his daughter do wrestle training. However, feminism has never been a slogan that can be easily shouted. Instead, feminist is the result of countless struggles. Feminism means accepting the question of "choosing” rather than relaxing life (KE, 2017).

\section{A Father \\ Although Mahavir has been a remarkable wrestling athlete and autocrat parent, he is a father of four daughters.}

\section{The Abandoned Religion}

India is a famous religious country in the world, while people in most parts of South India believe in Hinduism. One of the important precepts of Hinduism is to abstain from meats. Even today, the believers are still stubbornly adhering to the rules. and the younger generation who violate the precepts will often be forced to carry out a set of tedious rituals to purify the body and mind, and n more serious cases, they will even to be expelled from the home (MIN, 2004). In the film, there is an inconspicuous but very important detail. when Geeta and Babita are defeated repeatedly by her cousin during the wrestling practice, their father has made a big decision after deep consideration. In order to make daughters to enhance their physical strength, Mahavir resolutely and determinedly breaks the precept to kill the chicken and cook them. It means that he has abandoned his or his family's religious beliefs to achieve his dream when he decides to let his daughters eat chicken. Thus, the audiences were able to see his wife's intense reaction in the film that she not only forbids her husband using her kitchen, but also forbids her husband to take the pot back to the kitchen after cooked chicken. Because this act is the desecration of the gods. In the past, it is not to be regretted that father will be beheaded in public 10 times.

\section{The Abandoned Dignity}

After the father's high-pressure devil training, the girls begin to beat the men who are stronger than them one by one. They are regarded as legends and accepted by people gradually, including those who despised and detested them before. when they win the respected of people by impressive results, and when they win the national championship, and then are going to make a figure in the international arena, Geeta comes to the National Institute of Physical Education to receive a more professional guidance, see the wider world. During a visit home, after taunting her father for his old techniques, she defeats her ageing and visibly exhausted father in a ferocious bout that ensues. Babita tells an unrepentant Geeta that she shouldn't forget their father's techniques and reminds her that she owes all the success to him. This scene implies that the growth of the daughter and the decline of patriarchy. Although Geeta defeated the father, because of the coach's wrong guide, Geeta is defeated repeatedly in the international competition. Finally, Geeta asks to father for help in tears. Has heard helpless 
crying and remorse from his loved daughter, Mahavir resolutely quits his work, and comes to guide Geeta again. After the defendant issued, the Sports committee asks to dismiss Geeta, Mahavir abandoned the previous strong posture and puts down his dignity to the president. Mahavir begins to beg to give his daughter a chance, because he believes that Geeta has the ability to win the gold medal for the country. This is the first time in Mahavir's life toplead with a person for pity. If it were not out of the love of his daughter, he would not forsake his faith and dignity.

\section{The Expectation to Daughters}

Women in Indian have no social status, girls' fate is almost destined just when they born, especially the customs about marriage there make people feel weird. In Dangal, Mahavir lives in a place which is a remote feudal village. The villagers derided Geeta and Babita wearing “men’s shorts”, cutting “men’s hair style”. In their view, women are born to obey the three obediences and the four virtues. As for wrestling? It's not a matter that woman can do. Such terrible life environment and way of thinking represent the tens of thousands of small villages in India, and reflecting the most authentic third estate in Indian (TONG, 2017). When an Indian man marries his wife, he can not only get a considerable dowry, but also a slave heads to his will. What the most terrible is if the Hindu girl has no dowry, or the amount of dowry doesn't meet the man's request, the woman is more likely to be bullied after she married, even is tortured to death (Xiaohong, 2002). Combine with this background, the father in this film has no discrimination and indifference to his wife and four daughters. He loves them, although he is still the master with sheer power in this family, but he encourages his daughter to fight against the patriarchal society and control her own destiny. On the eve of the finals, Geeta asks his father for strategy, and his father said:

There is only one strategy tomorrow, that is to make people remember you ... People could remember you when you get the gold medal. Your victory will be the example for girls, countless girls will join you against those who discriminate against women ... Your opponent is not Angelina at tomorrow, but is fighting against all those people who discriminate against women ... If you win tomorrow, you will not enjoy the victory alone, there will be thousands of girls like them to share the victory with you, it is the victory of the girls who are imprisoned in the drudgery of housework, the victory of all the girls who are considered inferior to men, the victory of the girls who can only serve their husband and teach their children. (Dir. Tiwari, 2016)

Even the father imposed his dream on his daughter and forced her daughter to practice wrestling with majesty at the beginning. But champions were never forced to be, since the first time Geeta taking the match is no longer for her father, but for herself. They know there is no retreat, the father's dream has become their dream, their future, the only way to escape from this hell. In the final, the father was locked in the house, and unable to guide his daughter, but Geeta won the game entirely by herself. This shows that the girl has grown up and has begun to take full control of her destiny.

\section{Conclusion}

Dangal is an inspirational sports and family-themed film. After a North America premiere on 21 December 2016, Dangal was released worldwide on 23 December opening to positive response with critics; praise centered on the film's “honest” depiction of a real-life story and Khan's performance. It was also screened at the Beijing International Film Festival in April 2017 and second BRICS festival in June 2017 (Atul, 2017). From the film 
itself, the success of Dangal is fully benefited from its own perfect level of completion, story of tight, warmth and punchline, the appropriately background music and dedicated actors. As a feature film, there is little miss. The father of the film, is a man who makes unremitting endeavor for the gold medal dream and owns a high sense of national responsibility as well; he is an authoritarian parent in family education; he is a father loves his daughter. Although he is misunderstood by all the people initially, he spends his life proving that he is right: he is not an autocrat, but an ordinary father.

\section{References}

Atul, A. (2017). China's 'Dangal' mega-success echoes at second BRICS film festival. The Hindu.

Dir. Tiwari, N. (2016). Dangal. UTV Motion Pictures, Iqiyi.Web.<http://www.iqiyi.com/v_19rr80k1as.html?vfm=2008_aldbd>

Kate, M. (2000). Sexual Politics. Jiangsu Publishing House.

Ke, X. (2017). Choice of love-Thoughts of Dangal. Yunnan: Tax Paying.

Min, L. (2004). On the influence of Hinduism on Indian women. Sichuan: South Asian Studies Quarterly.

Tong, R. (2017). The impact of Dangal on Indian women's independence. Heilongjiang: Northern literature.

Xiaohong, T. (2002). Status of Indian women in the family. Guangdong: South Asian Studies. 